Portland State University

PDXScholar

\title{
Measuring the Support Networks of Transition-Age Foster Youth: Preliminary Validation of a Social Network Assessment for Research and Practice
}

Jennifer E. Blakeslee

Portland State University, jblakes@pdx.edu

Follow this and additional works at: https://pdxscholar.library.pdx.edu/socwork_fac

Part of the Family, Life Course, and Society Commons, Social Policy Commons, and the Social Work Commons

Let us know how access to this document benefits you.

\section{Citation Details}

Published as: Blakeslee, J.E., Measuring the support networks of transitionage foster youth: Preliminary validation of a social network assessment for research and practice, Children and Youth Services Review (2015), doi: 10.1016/j.childyouth.2015.03.014

This Post-Print is brought to you for free and open access. It has been accepted for inclusion in Social Work Faculty Publications and Presentations by an authorized administrator of PDXScholar. Please contact us if we can make this document more accessible: pdxscholar@pdx.edu. 
Measuring the support networks of transition-age foster youth: Preliminary validation of a social network assessment for research and practice

\author{
Jennifer E. Blakeslee, jblakes@pdx.edu, 503-725-8389 \\ Regional Research Institute for Human Services \\ Portland State University, School of Social Work \\ 1600 SW 4th Avenue. Suite 900 \\ Portland, OR 97207-0751
}

\begin{abstract}
:
Multi-dimensional social support is an important factor in any positive transition into young adulthood, and youth who are exiting foster care ideally receive comprehensive social support from a range of informal and formal sources. Yet the social networks of transition-age foster youth are likely influenced over time by child welfare involvement, which can weaken or disrupt natural support relationships, while introducing service-oriented relationships that are not intended to last into adulthood. To better understand the social support context of youth aging out of care, we can apply social network theory and methods to systematically identify their networks of supportive relationships and explore support provision as a network-based indicator. This paper presents a methodological approach to measure foster youth support networks, and describes these networks in terms of their capacity to provide support as a function of size, composition, and density, and in terms of actual support provision through identified relationships. Such a measurement approach should be systematic and reliable over time, and capture social support constructs relevant to practice with this population; preliminary inter-item
\end{abstract}


and test-retest consistency findings are promising, and the method demonstrates construct and predictive validity in comparison with a measure of perceived availability of social support.

KEYWORDS: foster care, aging out, social support, personal networks, network mapping 


\section{Introduction}

By policy, out-of-home foster placement is a social network intervention to connect children and youth to comprehensive resources through a combination of formal services and informal support, including the maintenance of existing connections to family and community. Ideally, these networks are structured in a way that allows formal and informal support providers to monitor behavior and communicate resource needs, much as a functional family network does (Coleman, 1988; Wellman \& Frank, 2001). Family-based (or family-like) network functionality likely plays a critical role in providing support and resources to transition-age foster youth (Blakeslee, 2012), and the experiences of many youth exiting care suggest that this is often the case (e.g., Cashmore \& Paxman, 2006; Collins, Spencer, \& Ward, 2010; Daining \& DePanfilis, 2007). However, youth transitioning from the foster care system often experience discouraging outcomes that indicate a lack of adequate resources and support in their social networks following child welfare intervention (e.g., Courtney et al., 2011; Cunningham \& Diversi, 2012). Recognizing the risk factors faced by many older youth exiting foster care, and reflecting the growing evidence from large panel studies documenting relatively poor transition outcomes (see Stott, 2013, for a recent review), there is an emerging consensus about the critical importance of multi-dimensional social support and comprehensive service provision as these youth transition to independence (Avery \& Freundlich, 2009; Courtney, 2009; Daining \& DePanfilis, 2007).

Specifically, there is an understanding that successful foster care transitions likely unfold in the context of both formal services and long-term informal support relationships (e.g., Collins, Spencer, \& Ward, 2010), and for some older youth in care, extended foster placement has likely hindered the development of this ideal support structure (e.g., Blakeslee, 2012; Collins, 2001). The population of youth aging out of care have likely experienced placement instability 
(Courtney, Piliavin, Grogan-Kaylor, \& Nesmith, 2001; McCoy, McMillen, \& Spitznagel, 2008;

McMillen \& Tucker, 1999), non-relative foster or group care (Keller, Cusick, \& Courtney, 2007; Wulczyn, Kogan, \& Harden, 2003), and residential treatment (McMillen \& Tucker, 1999). Thus, a history of social network disruption and a potential lack of long-term relationships during adolescence may also be presumed (Samuels, 2009). In many cases, such network disruption results in sparse social networks (Collins, 2001, 2004; Perry, 2006), disengagement from formal services (Goodkind, Schelbe, \& Shook, 2011; Keller et al., 2007; McCoy, et al., 2008), problem behaviors (James, Landsverk, \& Slyman, 2004; McCoy, et al., 2008; Newton, Litrownik, \& Landsverk, 2000), and other social adjustment challenges that may affect relationship development (Kools, 1999; Samuels \& Pryce, 2008; Unrau, Seita, \& Putney, 2008).

Such networks may not be adequate to meet the support functionality we associate with typical family-based (or family-like) constellations comprised of stable relationships that can effectively monitor youth well-being and facilitate resource provision (Coleman 1988: Wellman \& Frank 2001). This may be especially important for youth transitioning from foster care, many of whom experience individual and circumstantial needs that require the support of a network characterized by the presence of both personal and service-providing relationships connected to each other by collaborative interaction over time. This scenario of established and interconnected relationships may be more likely for youth who have had stable out-of-home placements in family-based settings, but we can assume a subgroup of foster youth who have few regularly supportive network members and few collaborative ties between members, which inhibits support provision (Pescosolido 1992; Stiffman et al. 2004). Because network disruption interrupts the availability of social support (Perry, 2006; Wellman \& Wortley, 1990; Wellman \& Frank, 2001), and because exiting foster care likely ends many child welfare services and 
established relationships with providers (Courtney et al., 2001; McMillen \& Rhagavan, 2009;

Samuels, 2008, 2009), it is presumed that many youth exit foster care without the multidimensional resources and long-term support that adolescents usually receive through stable family-based networks (Avery \& Freundlich, 2009; Collins, 2004; Samuels, 2008, 2009).

Though the concept of a "social network" has been applied to describe foster youth access to social resources, this has generally been measured as youth-perceived availability of functional support (e.g., Cashmore \& Paxman, 2006; Courtney, et al., 2005; Daining \& DePanfilis, 2007). Research has also begun to explore the psychological effect of network disruption (Perry, 2006) and the compositional characteristics of youth-identified networks during the transition from care (Collins, et al., 2010; Jones, 2013; Samuels, 2008). Further, a growing body of research demonstrates the importance of non-parental adults as sources of multi-dimensional support for older youth in care (Ahrens et al, 2011; Collins, et al., 2010; Greeson, Usher, \& Grinstein-Weiss, 2010; Munson \& McMillen, 2009), and current efforts are addressing the development of a network of supportive relationships as a primary outcome (e.g., Greeson, Garcia, Kim, \& Courtney, 2014; Nesmith \& Christopherson, 2014).

However, it has been argued that this research field is not yet distinctly informed by social network theory or methods (Blakeslee, 2012). Such an approach can contextualize support provision in a wider social structure by defining and measuring the network ties between an identified set of individuals, which may reflect emergent network processes and properties related to youth outcomes (Wellman, 1983, 1988). For example, the social support a foster youth receives may be related to the overall capacity of the network to provide support, the range of member social categories or the presence of specific roles, or the stability of members over time, all of which reflect network-level factors extending beyond direct interaction with youth. 
This study demonstrates a preliminary application of network theory and methods within a broad research agenda proposed by Blakeslee (2012) to consider network characteristics as an explanatory factor in foster youth transition outcomes. This paper introduces the support network assessment tool used here, demonstrates the reliability of the measurement of two support network constructs - network capacity and support provision-over two time points, and examines the validity of the network-based social support indicators relative to a standardized measure of perceived social support. The following section details these study aims, including the theoretical and empirical considerations that informed the measurement approach.

\section{Study Aims}

The overall aim of this study is to introduce a method to assess social network constructs relevant to support provision to transition-age foster youth. This approach specifically draws on a branch of social network research assessing social support in personal networks (e.g., Agneessens, Waege, \& Lievens, 2006; Tracy, Whittaker, Pugh, Kapp, \& Overstreet, 1994; Wellman \& Frank, 2001). Generally, personal networks include a focal person's strong, multidimensional ties to family and kin, which are usually relied on for day-to-day support and significant aid, as well as the various relationships which may provide less frequent and contextspecific support (e.g. Wellman \& Gulia, 1999; Wellman \& Wortley, 1990). This study defines a youth's personal support network as any formal ties to service providers (e.g., case workers, counselors, etc.) and informal ties to family, friends, and community, which youth identify as supportive. Support provided through these relationships is considered in terms of three standard social support types: emotional, informational, and concrete (e.g., Tracy \& Whittaker, 1990).

\subsection{Support network capacity}

The first goal of this paper is to describe the potential support capacity of these personal 
networks, in terms of overall network size, which in this case is the number of people youth name as providing support in general, network density, or the degree of interconnecting ties between these identified network members, and network range, in terms of the diversity of member social categories or roles. Structural measures of size and density are important correlates of support provision, where network size reflects support capacity, in that being connected to more people increases potential support (e.g., Barerra, Sandler, \& Ramsay, 1981; Walker, et al., 1993), and more interconnecting ties within a group of people increases the relational "bandwidth" (Kadushin, 2012, p. 105) through which needs can be monitored and support provided to network members. Importantly, density and size are generally presumed to be negatively correlated (Kadushin, 2012) — in that the larger a network is, the less likely that all parties are able to sustain relationships with each other-and this structural pattern may be relevant in the networks of transition-age foster youth. For example, it may be that smaller but more densely interconnected networks indicate strong, multi-dimensional relationships that provide relatively more support per member (e.g. Marsden, 1987; Wellman \& Gulia, 1999); this kind of "embededdness" is associated with lasting relationships and reliable support provision (e.g., Degenne \& Lebeaux, 2005; Wellman \& Whortley, 1990). In this analysis, the network capacity construct includes network size in terms of the number of people identified as providing any support, the density indicator of the degree of interconnection between them, and how many of these members represent "core" support relationships that can be described more fully.

On the other hand, the diversity of network membership is another indicator that may influence the support capacity of these networks, given that different kinds of relationships are more likely to provide different kinds of support at different levels - this is also known as network range, or access to diverse information and resources attainable through network 
members from different social groups (Burt, 1992; Campbell, Marsden, \& Hurlbert, 1986; Granovetter, 1973). Specifically, it has long been understood that positive youth development "requires a balance of support from family, formal associations (teachers, counselors, etc.) and informal support systems such as friends and same-age peers" (Johnson, Whitbeck, \& Hoyt, 2005, p. 232, citing Cauce, Felner, \& Primavera, 1982) to provide a full complement of the various kinds of support that young people may need in different domains (e.g., informational support at school, or concrete support at home, etc.). Network range may be especially important for vulnerable youth populations, who can benefit from comprehensive support coverage through ties to diverse members offering targeted support when needed (e.g., Haines \& Hurlbert, 1992). Network range is associated with larger networks, and in a study with homeless and runaway youth, member diversity was predicted by network size (Johnson, et al., 2005): the more network members identified, the more likely they were to come from different social spheres.

Here, the presence or absence of network members from different social categories (family, friends, or other) is used as an indicator of the range of supportive relationships in these networks. Further, there is particular interest in parent figures and formal service-providing roles in these networks, which are presumed to be critical providers of different kinds of social support as youth transition from foster care; potentially, the presence and diversity of these selected roles in youth networks may be associated with types of social support provision. For example, we may expect adults in parent-figure roles to provide more emotional and concrete support, versus informational support (e.g., Wellman \& Whortley, 1989, 1990), which we may expect to be provided through youth relationships with people in formal service roles. Here, the range of member social spheres and the degree to which critical functional roles are represented will be considered as indicators of support network capacity. 


\subsection{Support provision}

The second aim of this paper is to examine the social support provided through these identified relationships and to connect this to structural network characteristics. The assessment used here defines the support network in terms of the relationships providing "any support in the last year" and maps these network members by category. Because functional networks tend to have a core-periphery structure (e.g., Morgan, Neal, \& Carder, 1996), these relationships are then narrowed down to describe the "core" supporters in terms of roles, relationship strength, and the provision of monthly support (see Appendix A for the network assessment instrument).

Importantly, this method is intended to guide the development and delivery of networkoriented interventions by measuring patterns of support provision. Many recent studies have shown that foster youth generally feel that support is available, as measured by the Medical Outcomes Study (MOS) Social Support Survey (Sherbourne \& Stewart, 1990), a global measure of perceived availability of support. For example, among emancipating youth in Israel, MOS scores were weakly predictive of subjective well-being, and youth felt supported "most of the time" on average (Dinisman, Zeira, Sulimani-Aidan, \& Benbenishty, 2013); in the same sample, readiness to leave care mediated a relationship between perceived support and life satisfaction (Dinisman, in press). Similarly, respondents in the seminal Midwest study report that support is usually available, and this is consistent over five waves between ages 17 and 26 (overall means of 3.8-3.93, where 4.0 is "most of the time"; Courtney et al., 2011). Further, although differences in MOS scores validated the presence of latent classes in the Midwest sample at age 17 (Keller, et al., 2007), all classes reported mean support close to "most of the time" (3.784.04), regardless of other transition readiness indicators. Next, there was a small but surprisingly positive relationship between the Midwest MOS scores and arrest, prompting the suggestion that 
perceived support "may not be potent enough to offset risks" for the most vulnerable young people (Cusick, Havlicek, \& Courtney, 2012, p. 28). This possibility is underscored by the finding that MOS scores (combined with a support sufficiency measure) moderated and mediated depressive symptoms in the Midwest sample, but there was a diminished buffering effect for more complex childhood experiences of maltreatment (Salazar, Keller, and Courtney, 2011).

These studies suggest that the perceived availability of global support may play a role in resilience and coping (e.g., Cohen, 2004) among transition-age foster youth, but the mixed findings using this support measure are not instructive for intervention design and delivery to address the relatively poor outcomes experienced by this population. On the other hand, grounding support availability in terms of the provision of help through an identified network of relationships may be a more realistic and predictive measure for intervention-related assessment of social resources. This paper introduces a network-based measure designed to systematically assess support provision through current relationships, with the expectation that such support will be associated with indicators of network capacity, such as network size, density, and range. Here, the support provided through each relationship is considered as an aggregate network score, overall and by support type, and by average support per relationship.

\subsection{Reliability and validity}

The final aim of this paper is to begin to establish the conceptual and substantive value added by systematically measuring support network relationships in this manner, including estimating measurement reliability and exploring validity. Demonstrating internal consistency, in terms of expected relationships within and between the constructs of interest, is a first step in estimating reliability. Specifically, it is expected that network size will be negatively associated with network density, such that larger networks are less interconnected, and positively associated 
with network range and role diversity, such that naming more network members is correlated with broader representation of social categories or roles. Additionally, given the assumption that network capacity influences actual support provision, it is expected that indicators of size and diversity will be positively associated with support. First, total support is a function of network size as operationalized here, and the number of network members named should show consistent association with total support provided, overall and by type; conversely, the support-per-tie indicator controls for network size, and this average member "supportiveness" measure is not expected to be associated with network capacity or total support. Second, the degree of categorical range (presence of family, friends, and/or other) and core role diversity (presence of a parent figure, service provider, and/or other) are expected to increase the breadth and depth of potential support, thereby increasing support provision by type and overall.

Next, an adapted test-retest approach can further establish the accuracy of measurement over time. It is anticipated that confirmatory correlation between the measurement points will be attenuated by expected changes in the support networks during the interval, given the developmental stage of the participants as well as network disruption associated with the transition from foster care placement and associated services. Moderate to strong correlation would indicate reliability, and further analysis can determine whether interviewer effects are influencing the reliability of network measurement (Marsden, 2003).

Lastly, the validity of the support provision indicators would be demonstrated in comparison with an established measure of perceived social support, in terms of the degree to which the network indicators seem to measure similar support constructs, as well as the relative utility of the network-based support indicators as predictive of outcomes of interest, above and beyond what would be captured with a perceived social support measure. 


\section{Methods}

\subsection{Participants}

This study uses data collected for the evaluation of a pilot mentoring program at an urban non-profit Independent Living Program (ILP) provider in the Pacific Northwest. The program was designed for young adults with recent or current foster care experience who were enrolled in post-secondary education or training, with a focus on increasing academic support and career preparation by matching youth with volunteer mentors who had successful post-secondary backgrounds. An IRB-approved evaluation assessed the effect of the program on youth postsecondary enrollment, career preparation activities, and network-based support provision. Participants were recruited through the ILP, other local foster youth programs, and college programs serving youth with foster care experience; thus, this sample represents a relatively service-connected population of young adults with foster care experience. Eligible youth were invited to take part in the mentoring program and/or in the evaluation data collection, which created a non-equivalent comparison group of youth who chose not to be matched with a mentor. This study examines the support network measurement approach developed for the evaluation and pools the network data from the program and comparison groups for all analyses.

Table 1 shows the sample demographics. Participants were young adults (age 18 or older) with foster care experience who were either enrolled in a post-secondary education or career training program, or who planned to enroll within six months of the start of the study. Foster care experience was determined by their previous eligibility for ILP or college-based services for current and former foster youth, and $72 \%$ of baseline participants were enrolled in ILP services at the time of recruitment. Current or former foster care status was not collected, although $44 \%$ of participants indicated that they were living with foster family at baseline, and an additional 
portion may have been living in independent placements or with their families of origin while remaining under state guardianship. $65 \%$ of the baseline sample was female, $53 \%$ were White, $21 \%$ were Black/African-American, and $12 \%$ identified as Hispanic. $76 \%$ were attending community college and $18 \%$ were enrolled in other post-secondary programs. There were no statistically significant differences between the program and comparison groups by age, race/ethnicity, or living situation.

\section{[TABLE 1 ABOUT HERE]}

\subsection{Data Collection}

Baseline data collection (Time 1, hereafter, "T1") took place between January and March of 2011 with 34 participants (21 in the program group, 13 in the comparison group). Participants completed a paper-and-pencil assessment one-on-one with trained program staff $(n=14)$ or with this author $(\mathrm{n}=20)$ at the provider agency, on campus, in the community, or at their homes. Data collection took 30-45 minutes and youth were given $\$ 10$ gift cards to thank them for their time. This protocol was repeated at Time 2 ("T2"), with additional questions to assess measurement reliability and validity, and all $\mathrm{T} 2$ interviews were conducted by this author. T2 data collection took place between October and December of 2011 and the mean measurement interval was 7.37 months ( $\mathrm{SD}=.25)$. Note that the program was designed as a brief structured mentoring program (mentoring was expected to continue for at least 6 months), but follow-up data collection was delayed for some youth until the fall term was underway, to capture enrollment status following the summer, when many students would be expected to take a break from school. At T2, 10 of the comparison group participants were retained (77\%) and 17 of the program group were retained $(81 \%)$, for an overall retention rate of $79 \%$. There were no statistically significant differences in retention rate by age, race/ethnicity, living situation, or program group. 


\subsection{Measures}

\subsubsection{Support network assessment}

The network instrument was developed to measure the quantity and quality of supportive connections before and after a brief mentoring program to increase academic and career support. The network "map" and "grid" used here are adapted from instruments developed by Tracy and Whittaker (1990) to assess client support networks in practice (also adapted by others for various populations: e.g. Kef, Hox, \& Habekothe 2000; Robertson, et al., 2001; Tracy \& Johnson, 2007; Tracy \& Martin, 2007). (Though conceptually aligned, a distinction here is measurement of the interconnecting relationships between all identified names on the network map.) Table 2 describes the operationalization of the indicators for the network capacity and support provision constructs, as collected using the support network map and core relationship grid (Appendix A).

First, the network map was used as a name generator (Campbell \& Lee, 1991; Marsden, 2005; Marin \& Hampton, 2007) to brainstorm support network members ("who are the people who supported you in the last year?"). Respondents wrote down first names or initials only and situated these people in four map quadrants: family, friends, school/work, and other. Respondents were instructed to place people wherever they wanted to (e.g., "family" could include anyone they considered family), with an additional prompt that "other" might include people like a supportive caseworker, counselor, or mentor. The number of names on the support network map is one indicator of network size here, and the number of map categories with at least one person providing support in the last year (0-3) is used as a measure of network range (note that the categories for "school/work" and "other" were combined for analysis because there was little consistency in which of these were used for commonly identified formal roles, such as life skills workers or academic advisors). Respondents were next asked to indicate, to the best of their 
knowledge, the presence of interconnecting relationships between the people they placed on the map; these ties are used to calculate network density.

To identify and describe the more regularly supportive "core" network, respondents were asked to indicate which of the people on the network map provided support "at least monthly"; these names were transferred to the core relationship grid, which details three relational dimensions (type, content, and characteristics; Campbell \& Lee, 1991) for up to ten core network members (note that personal network measurement often minimizes respondent burden by limiting the number of relationships described in detail; Marsden, 2005). Next, respondents described the social role of each core network member (e.g., mom, boyfriend, teacher, etc.); these descriptions were later coded by the researcher as: (1) parenting or parent-figure roles, defined as mothers and fathers, step-parents, foster parents, grandparents, and aunts or uncles; (2) service-oriented roles, defined as child welfare and ILP caseworkers, post-secondary teachers and staff, or any other paid service-providers; or (3) other.

Next, respondents indicated the receipt of each of three support types (emotional, informational, and concrete; e.g., Tracy \& Whittaker, 1990) from each person, as provided within each of four program domains of interest (academic, career, extracurricular, and social). The instructions included examples of what each support type might look like in different domains to promote participant understanding, and the support types were given non-academic labels so that for each network member, respondents circled whether they "talk to them" (emotional), "get information/guidance" (informational), and/or "ask for favors" (concrete) within each domain. This provides a support count up to 12 for each core relationship. Participants could describe up to ten core relationships, for a total support score up to 120, or up to 40 for each support type. 
Although not reported here, respondents also described relational characteristics of frequency, closeness, and duration, which are common measures of tie strength (Marsden \& Campbell, 1984). Networks were measured twice following the same protocol, with additional probing at follow-up about network member turnover and potentially forgotten ties (as in Feld et al., 2007; Wright \& Pescosolido, 2002).

\section{[TABLE 2 ABOUT HERE]}

\subsubsection{Perceived social support}

The 19-item Medical Outcomes Study Social Support Survey (MOS; Sherbourne \& Stewart, 1991) has been used in outcome studies with this population (e.g., Courtney et al., 2005) to measure the perceived availability of various support functions (e.g., someone to give you information to help you understand a situation) on a 1-5 scale (none, a little, some, most, or all of the time). The MOS measures support overall and by subscale: emotional/ informational, tangible, affectionate, and positive social interaction. The Cronbach's coefficient for the subscales and overall is excellent in this sample, with $\alpha=.982$ at Time 1 and $\alpha=.945$ at Time 2 .

\subsubsection{Post-secondary enrollment}

Participants were enrolled in post-secondary education or career training programs at baseline, or were expected to enroll over the course of the 6-month mentoring program (Table 2). At Time 2, $70 \%(\mathrm{n}=19)$ were still enrolled, $22 \%$ were not enrolled, and $7 \%$ had graduated since Time 1 . Of the $22 \%(n=6)$ who were not enrolled at T2, one of these was someone who intended to enroll at $\mathrm{T} 1$ and had not done so by $\mathrm{T} 2$. The remaining five participants who were not enrolled at T2 had been enrolled at T1; three of these participants considered themselves "on a break" at $\mathrm{T} 2$, and two indicated that they were not in school due to a pregnancy. T2 enrollment status was dichotomized (not enrolled versus enrolled or graduated) as an outcome for analysis. 


\subsection{Data Analysis}

\subsubsection{Descriptives}

Primary support network variables are reported for all baseline participants $(\mathrm{N}=34)$, including the number of people placed in each category on the network map, network density, the diversity of selected roles in the core networks, and support provision in total and by type.

\subsubsection{Reliability estimation}

Bivariate analysis of the parametric (Pearson's product-moment) and nonparametric (Spearman's rank) correlation coefficients was used to explore internal consistency, in terms of associations within and between the indicators for network capacity and support provision, as well as test-retest consistency of the baseline and follow-up measurements. Parametric and nonparametric analysis of variance was used to test for inter-rater effects in terms of group mean differences on the T1 indicators by whether the interviewer was this author $(n=20)$ or one of two program staffers $(n=14)$ (all T2 interviews were conducted by this author).

\subsubsection{Validity testing}

Convergent and discriminant construct validity and predictive criterion validity were tested. First, support provision construct validity was tested using bivariate correlation of the network support scores with the MOS subscale scores; these correlations were examined for demonstrations of convergent validity, in terms of expected associations between the separate measures of similar constructs, and discriminant validity, demonstrated by weak correlations between distinct constructs that are not expected to be related. Discriminant analysis also compared the MOS with the network capacity indicators. Predictive validity was tested using analysis of variance in the support provision and MOS scores by the outcome variable available for this study: enrollment in post-secondary education or training programs at follow-up. 


\section{Results}

\subsection{Descriptives}

\subsubsection{Network size}

As shown in Table 3, the baseline networks include about 11 supportive members on average. Respondents identify almost 7 of these people (64\%) as members of a more regularlysupportive core sub-network providing support at least monthly. The overall network size is comparable to personal network size measured similarly with a similarly-aged (18-22) homeless and runaway population (13 network members on average; Rice et al., 2011).

\subsubsection{Network density}

The average network density, or degree of interconnection between network members relative to all potential ties, is .27. Degenne and Lebeaux (2005) measured density similarly and report comparable interconnection $(M=.26-.31$ over three waves) in the personal networks (defined as "people who are important to you") of college-age youth. Using similar methodology for assessing interconnection in the networks of homeless and runaway youth, Rice and colleagues (2011) also report comparable density $(M=.20, S D=.21)$ between ties in personal network members who the respondent "interacted with" in the previous month.

\subsubsection{Network range}

The number of members participants could put in the network map categories was not constrained, and overall, these support networks are compositionally diverse, with three of four possible categories named $(\mathrm{M}=3.38, \mathrm{SD}=.70)$, though core networks are less diverse and tend to have between two and three $(\mathrm{M}=2.85, \mathrm{SD}=89)$ social categories represented. Overall, $91 \%$ $(n=31)$ of respondents named at least one person they categorized as Family, 94\% $(n=32)$ categorized at least one person as a Friend, 74\% $(n=25)$ put someone in the School/Work 
category, and $79 \%(n=27)$ placed at least one name in the Other category. Distinguishing which network members regularly provide support changes the categorical distribution: participants most frequently named members in the Friends category on the support network map, with Family a close second (see Table 3), but when respondents were asked to identify the core network members who provide them support at least once a month, they named more members categorized as Family than Friends, on average. Note that the network range indicator combines the School/Work and Other categories for bivariate reliability analysis, which results in a baseline support network range average of $2.82(\mathrm{SD}=.46)$.

\subsubsection{Core role diversity}

As shown in Table 3, cores include between one and two parenting roles and one and two service-oriented roles (as designated by the author) on average, with the remaining core ties categorized as other roles. Core role diversity measures the representation of each of these three classifications (on a scale of 1-3), and on average, core role diversity is 2.32 at baseline $(\mathrm{SD}=.73)$. The majority of participants have at least one person in a parent role (74\%), and about half $(47 \%)$ have more than one. Over half $(68 \%)$ of the core networks have at least one serviceprovider, and nearly half (47\%) have more than one service-oriented role; $38 \%$ of respondents specifically name an ILP case manager or a child welfare caseworker as a core support provider. About half (53\%) name at least one parent and one service role, and $29 \%$ specifically name at least one parent role plus an ILP or child welfare service-provider. Rice and colleagues (2011) report similar findings with homeless and runaway youth of similar age, with $44 \%$ of their respondents naming a caseworker as someone they interact with, and 50\% of the homeless and runaway respondents included a parent as someone they interact with (in this sample, 38\% specifically named a mother, father, or step-parent as a core tie). 


\subsubsection{Support provision}

Respondents could identify up to ten core network members providing support at least monthly. When networks are narrowed down to monthly supports, the core ties that were identified are providing at least half the potential support they could be providing, per tie, on average (6.65 mean support per tie, with a measurable range between 0-12). Emotional support is most often provided by core ties, followed by informational support, and lastly, concrete support.

\section{[TABLE 3 ABOUT HERE]}

\subsection{Measurement Reliability}

\subsubsection{Internal consistency}

Inter-item correlations were used to examine consistency within and between the network capacity and support provision constructs, and such consistency was demonstrated more clearly at T1 than T2 (Table 4 shows these coefficients as Pearson's $r$ or Spearman's rho $(\rho)$, depending on the normality of the variable distributions). Within network capacity, there is an expected relationship between network size and density at T1 (-.403), indicating that larger networks are less interconnected (not observed at T2). There were expected moderate associations between T1 network size and network range (.525), indicating that larger networks had names in more categories (not observed at T2). The number of potential core supports is contingent on overall network size, and there was expected consistency between network size and core size at both T1 and at T2 (.727 and .756). There was also an association between network range and core size (.399) and core role diversity (.347) at T1, indicating that more diverse networks were associated with more people providing core support through different roles (not observed at T2). At both T1 and T2, core network size was associated with role diversity (.605 and .385) as expected, in terms of the designation of core ties as parent figures or service providers. 
At both time points, there were expected medium to large correlations between all measures of network-based support provision, where the three support type totals are subscores, and where support per tie controls for core size. There were also expected associations between constructs: network size and core size were consistently associated with support (with the exception of network size and informational or concrete support at T2), but not with support per tie. Lastly, there were no associations between network range and the support variables at either time point, but there were moderate to strong relationships between core role diversity and total support (.362), and specifically emotional (.365) and informational support provision (.349) at $\mathrm{T} 1$, indicating that the range of core ties designated as parent, service, and/or other was positively associated with support provision at T1. However, these associations were not present at T2, and there was a negative relationship between T2 role diversity and support per tie (-.392).

\section{[TABLE 4 ABOUT HERE]}

\subsubsection{Test-retest reliability}

The test-retest correlations reported in Table 5 show preliminary evidence of measurement reliability on nearly all of the network indicators over an average interval of more than seven months. For the network capacity indicators of size and range, there were moderate to strong correlations over time, although core role diversity was weakly correlated at trend level. Reliability was not indicated for the measure of support network density. Further, many social category and role sub-measures were consistent over time, with the exception of the number of people categorized as School/Work/Other on the network map and the number of Friends in the core support network. The support provision construct has moderate test-retest correlation over time for all variables. Next, potential inter-rater measurement effects were examined because there were multiple raters at T1 and one rater at T2. Parametric and non-parametric analysis of 
variance on the T1 indicators listed in Table 3 showed one statistically significant group difference by rater: support network density was higher $(\mathrm{p}=.01)$ for participants interviewed by this author $(\mathrm{M}=.33, \mathrm{SD}=.20)$ compared to the other two interviewers $((\mathrm{M}=.18, \mathrm{SD}=.14)$.

[TABLE 5 ABOUT HERE]

\subsection{Measurement Validity}

\subsubsection{Construct validity}

To examine aspects of construct validity, the MOS indicators of the perceived availability of social support (Sherbourne \& Stewart, 1991) were compared to support provision captured by the network instrument. Bivariate correlations were run to test convergent and discriminant construct validity between the two measures. Table 6 shows multiple strong correlations $(\mathrm{p}<.05)$ between the MOS sum scores and subscale averages and the network-based support totals, confirming that the instruments are measuring related constructs similarly. For example, there is strong association (.642) between the network measure of informational support and the MOS emotional/informational support subscale. However, there were discriminant associations between measures of different kinds of support; for example, the network measure of informational support had weaker and non-significant correlation with the MOS subscales for positive interaction and affectionate support. Additionally, non-parametric bivariate analysis showed no statistically significant correlations between the MOS variables and the network capacity indicators at $\mathrm{T} 1$ or at $\mathrm{T} 2$. In other words, there is evidence that the two measures of support provision converge on related aspects of social support, and there is demonstration of discrimination between the MOS measure and the network capacity indicators, which are not expected to be directly related to perceived availability of support by function.

[TABLE 6 ABOUT HERE] 


\subsubsection{Predictive validity}

Analysis of predictive validity examined the relative association of the two measures of support on a program-relevant criterion, post-secondary enrollment at follow-up. The MOS and the network-based support scores were analyzed as independent variables with T2 enrollment (or graduation) as the dichotomous dependent variable differentiating groups. Table 7 shows that multiple indicators of support provision captured by the network instrument at both time points are predictive of enrollment at $\mathrm{T} 2$. However, there were no statistically significant differences on any of the MOS variables, although there was a similar non-significant pattern in the group means. This indicates that, in this study, network-based support provision was more predictive of the post-secondary enrollment outcome than the MOS measure of perceived social support.

\section{[TABLE 7 ABOUT HERE]}

\section{Discussion}

The purpose of this paper is to describe the administration of a support network assessment instrument with a specific population, to present relevant theoretical constructs as operationalized here, to demonstrate the reliability and validity of the measurement approach, and to discuss research implications and ongoing limitations in light of the findings.

First, the findings show that the relatively service-connected youth in this sample were able to name 11 support network members on average, with most network members categorized as family or friends. For about $27 \%$ of the potential ties between network members, respondents indicated that these people also had relationships with each other. The majority $(64 \%)$ of the network members provide some kind of support at least monthly, with youth most commonly receiving emotional support in various domains, followed by informational and then concrete support. Most youth (74\%) named at least one parent figure and most name at least one service 
provider (68\%) as a core supporter, and about half of the participants (53\%) name at least one person in each of these roles. These findings are comparable to methodologically similar network studies with young people (e.g., Degenne \& Lebeaux, 2005: Rice et al., 2011), which underscores the substantive relevance of this approach.

Overall, the reliability findings are mixed, though there are more demonstrations of reliability, both within and between measurement time points, than not. In the adapted test-retest approach, paired comparison of the network variables over time showed varying degrees of consistent measurement for nearly all of the indicators within the constructs of interest. With the exception of one variable — support network density - measurement of the indicators of network capacity and support provision showed moderate to strong correlation over time (with one variable, core role diversity, significant at the trend level). Additionally, the actual number of network members identified within social categories or roles was largely consistent over time, with the exception of the number of names categorized as School/Work/Other on the network map, and the number of Friends in the core networks This is reasonable, given expected change in these networks over the measurement interval, as well as the developmental stage of the participants, including expected transitions from foster care. Forthcoming analysis will explore how and why these network indicators changed over time.

Internal consistency was generally demonstrated in terms of the bivariate association of the indicators within and between the constructs at baseline, although many of these associations were not observed in the smaller sample at follow-up. Overall, the baseline data showed promising associations between support network size and how many social categories are represented overall, how many of these people provide core support, and whether these core relationships include parent figures and/or service-providers in addition to other roles. This 
confirms that these measures of capacity are related: the more names generated on the support network map, the more likely they come from multiple social spheres, within which regularly supportive core ties in various roles may be represented. The broader range may also explain why larger networks may be less interconnected. However, there were mixed findings for network density, which was negatively associated with network size as expected at baseline, but does not seem to have been reliably measured over time or between interviewers. Given that density is a primary structural indicator reflecting the added value of this kind of network-based approach, it will be important to continue to explore whether interconnection between network members is worth measuring as an indicator related to network capacity or support provision.

Next, the network capacity variables were consistently associated with support provision. This is expected, in that network size delimits the amount of support that can be measured using this instrument. Additionally, the selection of compositional measures as capacity indictors assumes that a broader range of social categories and specific roles will increase overall support. For example, we may expect that family members will be more likely to provide concrete versus informational support (e.g., Wellman \& Wortley, 1989, 1990), and naming more network members in the other categories would increase the informational support that is more likely to be provided by these different kinds of ties. However, the compositional indicators were not associated with support variables at either time point, with the exception of the core role diversity associations with support at $\mathrm{T} 1$, such that naming a range of parent figures, service providers, and/or other roles was associated with increased emotional and informational support; this pattern was not present at $\mathrm{T} 2$, where role diversity was negatively associated with support per tie (indicating that having more roles was associated with less support provided by each tie). This is not necessarily discouraging, in that we might expect role diversity to decrease support 
per tie in a network where, for example, multiple service providers supply targeted support in a specific domain, in addition to parent figures and other roles (e.g., friends), who may offer multidimensional support. This could also explain why baseline role diversity was associated with total support, as well as emotional and informational support specifically, in networks with broader representation of these various roles. Nonetheless, a clear relationship between network range and support provision is not shown, and it may be that social categories (as measured here) would be more reliably useful as tie-level indicators, instead of network-level measures of range or diversity. For example, whether a particular network member is in a parenting or a service providing role in a foster youth support network may be more directly linked to the kind of support provided through that relationship. Future research will explore such compositional indicators as dyadic or tie-level relational attributes, as opposed to network-level indices.

Network capacity is difficult to validate in this instance, due to the influence of the network size indicators as determinants of measurement capacity as operationalized here (i.e., a support network of two people will limit variance in the indicators of compositional diversity and support provision). However, it is notable that the internal consistency findings showed no association between network size and the average supportiveness of the ties within networks. This is important to remember when considering the variability of transition-age foster youth networks, especially if network assessment is used to guide intervention. For example, youth networks may be smaller and composed of highly-supportive relationships, or relatively small networks may be minimally supportive, just as larger networks may provide lower or higher levels of support per tie. In this case, network capacity is a support ceiling that can potentially be raised for smaller networks at various levels of support per tie, just as average supportiveness can potentially be raised for larger networks providing lower levels of support through each tie. 
The construct validity findings further demonstrate the relevance of the support indicators measured here in comparison with the selected measure of perceived social support. There were multiple large correlations between the MOS scores and the support provision assessed by the network instrument, indicating convergent validity between the measures; further, the MOS scores were not associated with other network properties, indicating discriminant validity between theoretically-unrelated constructs. Additionally, comparison of the support provision indicators with the measures of perceived support demonstrated the relative predictive validity of the network-based indicators. The MOS has been used in major studies with this population (e.g., Courtney, et al., 2005), and thus it was reasonable to compare the two measures on the primary outcome variable available for analysis: participant enrollment as post-secondary students. The network support scores at both baseline and follow-up predicted secondary education or training enrollment, whereas none of the indicators of perceived support were associated with this outcome. Although not conclusive, these findings demonstrate the utility of the network instrument - specifically the operationalization of support provision through systematicallyidentified core relationships - to meaningfully measure network-based social support.

The predictive finding for support provision over perceived support availability was not specifically hypothesized, and generates a number of potential explanations. First, as discussed in the earlier review of recent studies measuring perceived support with foster youth (see Section 2.2 above), the MOS was used as a measure of informal support with separate indicators for perceptions of support from service providers or other formal roles. This is not surprising, as this global support survey was specifically designed for medical outcomes research, and many of the subscales, as well as the tangible support examples, reflect support that we might expect family or close friends to provide (e.g., "someone to help you if you were confined to a bed"). This may 
not capture the range of support a transition-age foster youth might seek from their networks, both in terms of some kinds of service providers (e.g., an academic counselor), as well as natural mentors, such as a coach or spiritual advisor, or a near-peer relationship providing contextspecific guidance at school or work. Such relationships may more directly influence outcomes (e.g., Ahrens, DuBois, Richardson, Fan \& Lozano, 2008; Greeson, Usher, \& Grinnstein-Weiss, 2010; Munson \& McMillen, 2009), and may not be captured by global support measures alone. For transition-age foster youth, even those who are relatively high-functioning, global perceptions of support availability may reflect an aspect of resilience, and the belief that help will be available in case of need accounts for much of the buffering effect of social support (Cohen, 2004). However, in the absence of normative family networks that can be relied on in the event of typical crises large and small during the transition to adulthood, it may be more relevant to assess the actual provision of support through specific relationships. This is especially important in child welfare research and practice, which must address whether all youth transitioning out of the formal support system can identify a network of relationships providing context-specific support adequate to meet their individual needs and aspirations.

\subsection{Study limitations}

The preceding findings are presented in light of study limitations. First, generalizability is an important consideration. This analysis uses evaluation data from a mentoring program for transition-age youth with foster care experience who are enrolled, or plan to enroll, in postsecondary education and training programs. Although participants were recruited through college programs serving youth with foster care experience, most were referred by the Independent Living Program, which is itself a referral-based service for older youth in care who are considered ready to regularly participate in structured skill-building and transition planning. 
Foster youth who have larger or more connected networks may be more likely to receive a degree of support that facilitates their participation in ILP services and/or post-secondary education, and this suggests future network studies with a broader population of transition-age youth with foster care experience, and also development of hypotheses regarding serviceconnected (and potentially higher-functioning) subgroups of youth. Therefore, this study is limited in that it is not generalizable to all transition-age youth in foster care, but is somewhat generalizable to those who are attending post-secondary programs and/or receiving ILP services.

Next, the design of the program evaluation from which this sample was drawn allows for pooled data analysis including program participants and a non-equivalent comparison group that did not receive the intervention. However, this small convenience sample is potentially underpowered to detect differences in retention, for example, by program group, race/ethnicity, or living situation, which would weaken the justification for using the pooled follow-up data. In recognition of the small sample size, non-parametric statistical tests were employed in many cases as a form of sensitivity analysis. Future studies with of a wider range of transition-age foster youth would mitigate limitations related to the size of the sample used here; conversely, the exploratory nature of the broader study from which these findings are drawn introduces a risk of Type I error, due to the breadth of analysis conducted (only some of which are reported here).

Next, there are particular reliability concerns around asking respondents to report on the presence of ties between other network members, as shown in the mixed density findings reported here. This is a common and practical approach in personal network research (Marsden, 2005; Wellman, 2007) — and a recent study with homeless and runaway youth of comparable age also used a "map" to generate names and then asked who in the network "likely knew" each other (Rice, Milburn, \& Munro, 2011)—but is nonetheless a limitation. Ideally, measurement 
includes confirmation of any inter-relationships between identified network members with those members directly (this is also a way to implement sensitive relationship reciprocity measures), or alternatively, one can interview a few members that know the network well (Campbell \& Lee, 1991; McCarty, 2002). This is expected to be an ongoing limitation, and future research efforts will attempt some confirmation of youth-identified network structure, particularly for ties of substantive interest (e.g., between formal and informal support providers in the network).

Lastly, the network instrument presented here is intended to be flexible as far as what relational content is measured - ideally, a different kind of program or study could measure fewer or different domains or support types, for example. However, there are measurement concerns related to the program domains used in this case (academic, career, extracurricular, and social). These domains were of interest in evaluating the mentoring program, but participants expressed confusion in distinguishing between them. The domains were therefore collapsed as a 0-4 support score for this analysis, which may introduce error. Future research efforts will measure support in fewer and/or more generalized transition support domains.

\subsection{Conclusion}

This paper introduces a personal network measurement protocol designed for application with transition-age foster youth, demonstrates preliminary measurement reliability for the network indicators, and establishes the validity of support network constructs of interest. An imperative of social work research is practical relevance, and the current study demonstrates how network methodology can be used to distinguish network capacity and support provision in terms of the amount and variability of formal and informal sources of social support as youth transition out of foster care. This small-scale effort describes a replicable method to gather a great deal of reasonably reliable and multi-dimensional social network data in the time it takes to complete an 
average program evaluation survey; repeating such measurement over time easily widens the investigative scope to allow for further consideration of network stability and member turnover.

The introduction of this approach is timely, given the field's recent emphasis on networkbased support as a critical factor in improving foster care outcomes. Additionally, this method is robust for application with foster care subpopulations, including youth with disabilities, who may be underrepresented in child welfare research (Blakeslee et al., 2013). This approach also accounts for important formal (e.g., mentors; Keller \& Blakeslee, 2013) and informal (e.g., siblings: McBeath et al., 2014) relationships which may be sensitive to social network disruption due to foster care placement. Additional findings from this research, including analysis of support network stability and member turnover, are forthcoming. Future testing will broaden examination of network indicators as predictive of other foster youth outcomes of interest.

Lastly, it has been argued that child welfare research is under-informed by mainstream social science theory (e.g., Berridge, 2007; Stein, 2006). The network concepts used here are well-established in social science, and have been used to explain how network characteristics influence, and are influenced by, experiences in the transition to young adulthood (e.g., Bidart \& Lavenu, 2005; Degenne \& Lebeaux, 2005). Additionally, related network concepts and methods have advanced explanatory research with a population of adolescents with non-typical support networks, homeless youth (see Barman-Adhikari \& Rice, 2014, and de la Haye, et al., 2012, for two recent examples). This study is presented an initial step in a larger agenda to use social network concepts to explain how long-term foster care placement may alter the development of a normative support network with the capacity to guide youth into young adulthood, and to contribute to network-informed policy and practice innovations that increase support provision to youth during the transition from foster care and other public service systems. 


\section{References}

Ahrens, K. R., DuBois, D. L., Garrison, M., Spencer, R., Richardson, L. P., \& Lozano, P. (2011). Qualitative exploration of relationships with important non-parental adults in the lives of youth in foster care. Children and youth services review, 33(6), 1012-1023.

Ahrens, K. R., DuBois, D. L., Richardson, L. P., Fan, M. Y., \& Lozano, P. (2008). Youth in foster care with adult mentors during adolescence have improved adult outcomes. Pediatrics, 121(2), e246-e252.

Agneessens, F., Waege, H., \& Lievens, J. (2006). Diversity in social support by role relations: A typology. Social Networks, 28(4), 427-441.

Avery, R. J., \& Freundlich, M. (2009). You're all grown up now: Termination of foster care support at age 18. Journal of Adolescence, 32(2), 247-257.

Barman-Adhikari, A., \& Rice, E. (2014). Social networks as the context for understanding employment services utilization among homeless youth. Evaluation and Program Planning, 45, 90-101.

Beggs, J. J., Hurlbert, J. S., \& Haines, V. A. (1996). Revisting the rural-urban contrast: Personal networks in nonmetropolitan and metropolitan settings. Rural Sociology, 61(3), 407-426

Berridge, D. (2007). Theory and explanation in child welfare: education and looked after children. Child and Family Social Work, 12(1), 1-10.

Bidart, C., \& Lavenu, D. (2005). Evolutions of personal networks and life events. Social Networks, 27(4), 359-376.

Blakeslee, J. E. (2012). Expanding the scope of research with transition-age foster youth: applications of the social network perspective. Child \& Family Social Work, 17(3), 326336. 
Blakeslee, J. E., Del Quest, A., Powers, J., Powers, L. E., Geenen, S., Nelson, M., ... \& McHugh, E. (2013). Reaching everyone: Promoting the inclusion of youth with disabilities in evaluating foster care outcomes. Children and Youth Services Review, 35(11), 18011808.

Burt, R. S. (1992). Structural Holes: The Social Structure of Competition. Cambridge, MA; Harvard University Press.

Campbell, K. E., \& Lee, B. A. (1991). Name generators in surveys of personal networks. Social Networks, 13(3), 203-221.

Campbell, K. E., Marsden, P. V., \& Hurlbert, J. S. (1986). Social resources and socioeconomic status. Social Networks, 8(1), 97-117.

Cashmore, J., \& Paxman, M. (2006). Predicting after-care outcomes: the importance of 'felt' security. Child \& Family Social Work, 11(3), 232-241.

Coleman, J. (1988). Social capital in the creation of human capital. American Journal of Sociology, 94(S1), S95-S120.

Collins, M. E. (2001). Transition to adulthood for vulnerable youths: A review of research and implications for policy. Social Service Review, 75(2), 271-291.

Collins, M. E. (2004). Enhancing services to youths leaving foster care: Analysis of recent legislation and its potential impact. Children and Youth Services Review, 26(11), 10511065.

Collins, M. E., Spencer, R., \& Ward, R. (2010). Supporting youth in the transition from foster care: Formal and informal connections. Child Welfare, 89(1), 125-143.

Courtney, M. E., Dworsky, A., Hook, J., Brown, A., Cary, C., Love., K., . . Bost, N (2011). Midwest Evaluation of the Adult Functioning of Former Foster Youth. Retrieved from 
http://www.chapinhall.org/research/report/midwest-evaluation-adult-functioning-formerfoster-youth

Courtney, M., Dworsky, A., Brown, A., Cary, C., Love, K., \& Vorhies, V. (2011). Midwest evaluation of the adult functioning of former foster youth: Outcomes at 26. Chicago: Chapin Hall Center for Children at the University of Chicago.

Courtney, M.E., Dworsky, A., Ruth, G., Keller, T., Havlicek, J., \& Bost, N. (2005). Midwest evaluation of the adult functioning of former foster youth: Outcomes at age 19. Chicago: Chapin Hall Center for Children at the University of Chicago.

Courtney, M.E., Piliavin, I., Grogan-Kaylor, A., \& Nesmith, A. (2001). Foster youth transitions to adulthood: A longitudinal view of youth leaving care. Child Welfare, 80(6), 685-717.

Cunningham, M. J., \& Diversi, M. (2013). Aging out: Youths' perspectives on foster care and the transition to independence. Qualitative Social Work, 12(5), 587-602.

Daining, C., \& DePanfilis, D. (2007). Resilience of youth in transition from out-of-home-care to adulthood. Children and Youth Services Review, 29(9), 1158-1178.

De la Haye, K., Green, H. D., Kennedy, D. P., Zhou, A., Golinelli, D., Wenzel, S. L., \& Tucker, J. S. (2012). Who is supporting homeless youth? Predictors of support in personal networks. Journal of Research on Adolescence, 22(4), 604-616.

Degenne, A., \& Lebeaux, M. (2005). The dynamics of personal networks at the time of entry into adult life. Social Networks, 27(4), 337-358.

Feld, S. L., Suitor, J. J., Hoegh, J. G. (2007). Describing changes in personal networks over time. Field Methods, 19(2), 281-236. 
Goodkind, S., Schelbe, L. A., \& Shook, J. J. (2011). Why youth leave care: Understandings of adulthood and transition successes and challenges among youth aging out of child welfare. Children and Youth Services Review, 33(6), 1039-1048.

Granovetter, M. (1973). The strength of weak ties. American Journal of Sociology, 78(6), 13601380.

Greeson, J. K., Garcia, A. R., Kim, M., \& Courtney, M. E. (2014). Foster youth and social support: the first RCT of independent living services. Research on Social Work Practice, 1049731514534900 .

Greeson, J. K., Usher, L., \& Grinstein-Weiss, M. (2010). One adult who is crazy about you: Can natural mentoring relationships increase assets among young adults with and without foster care experience?.Children and Youth Services Review, 32(4), 565-577.

Haines, V. A., \& Hurlbert, J. S. (1992). Network range and health. Journal of Health and Social Behavior, 33(3), 254-266.

James, S., Landsverk, J., \& Slymen, D. J. (2004). Placement movement in out-of-home care: Patterns and predictors. Children and Youth Services Review, 26(2), 185.

Johnson, K. D., Whitbeck, L. B, \& Hoyt, D. R. (2005). Predictors of social network composition among homeless and runaway adolescents. Journal of Adolescence, 28(2), 231-248.

Jones, L. (2013). The family and social networks of recently discharged foster youth. Journal of Family Social Work, 16(3), 225-242.

Kadushin, C. (2012). Understanding Social Networks. New York: Oxford University Press.

Kef, S., Hox, J. J., \& Habekothe, H. T. (2000). Social networks of visually impaired and blind adolescents: Structure and effect on well-being, Social Networks, 22(1), 73-91. 
Keller, T. E., \& Blakeslee, J. E. (2013). Social networks and mentoring. In D. L. DuBois \& M. J. Karcher (Eds.), Handbook of Youth Mentoring, Second Edition, pp. 129-142). Thousand Oaks, CA: Sage Publications.

Keller, T. E., Cusick, G., \& Courtney, M. E. (2007). Approaching the transition to adulthood: Distinctive profiles of adolescents aging out of the child welfare system. Social Service Review, 81(3), 453-484.

Kools, S. (1999). Self-protection in adolescents in foster care. Journal of Child and Adolescent Psychiatric Nursing, 12(4), 139-152.

Marin, A., \& Hampton, K. N. (2007). Simplifying the personal network name generator: Alternatives to traditional multiple and single name generators. Field Methods, 19(2), 163-193.

Marsden, P. V. (1987). Core discussion networks of Americans. American Sociological Review, 52(1), 122-131.

Marsden, P. V. (1990). Network data and measurement. Annual Review of Sociology, 16(1), 435463.

Marsden, P. V. (2003). Interviewer effects in measuring network size using a single name generator. Social Networks, 25(1), 1-16.

Marsden, P. V. (2005). Recent developments in network measurement. In P. J. Carrington, J. Scott, \& S. Wasserman (Eds.), Models and Methods of Social Network Analysis (pp. 830). Cambridge: Cambridge University Press.

Marsden, P. V., \& Campbell, K. E. (1984). Measuring tie strength. Social Forces, 63(2), 482501. 
McBeath, B., Kothari, B., Blakeslee, J., Lamson-Siu, E., Bank, L., Linares, L.O., Waid, J., Sorenson, P., Jimenez, J., Pearson, E., \& Shlonsky, A. (2014). Intervening to improve outcomes for siblings in foster care: Conceptual, substantive, and methodological dimensions of a prevention science framework. Children and Youth Services Review, $39(1), 1-10$.

McCarty, C. (2000). Structure in personal networks. Journal of Social Structure, 3(1), retrieved from http://www.cmu.edu/joss/index.html

McCoy, H., McMillen, J., \& Spitznagel, E. (2008). Older youth leaving the foster care system:

Who, what, when, where, and why? Children and Youth Services Review, 30(7), 735-745.

McMillen, J. \& Raghavan, R. (2009). Pediatric to adult mental health service use of young people leaving the foster care system. Journal of Adolescent Health, 44(1), 7-13.

McMillen, J., \& Tucker, J. (1999). The status of older adolescents at exit from out-of-home care. Child Welfare, 78(3), 339-360.

Morgan, D., Neal, M., \& Carder, P. (1996). The stability of core and peripheral networks. Social Networks, 9(1), 9-25.

Munson, M. R., \& McMillen, J. C. (2009). Natural mentoring and psychosocial outcomes among older youth transitioning from foster care. Children and Youth Services Review, 31(1), 104-111.

Nesmith, A., \& Christopherson, K. (2014). Smoothing the transition to adulthood: Creating ongoing supportive relationships among foster youth. Children and Youth Services Review, 37, 1-8. 
Newton, R. R., Litrownik, A. J., \& Landsverk, J. A. (2000). Children and youth in foster care: disentangling the relationship between problem behaviors and number of placements. Child Abuse \& Neglect, 24(10), 1363-1374.

Pecora, P. J., Kessler, R. C., O’Brien, K., White, C. R., Williams, J. Hiripi, E., English, D., White, J., \& Herrick, M. A. (2006). Educational and employment outcomes of adults formerly placed in foster care: Results from the Northwest Foster Care Alumni Study. Children and Youth Services Review, 28(12), 1459-1481.

Perry, B. (2006). Understanding social network disruption: The case of youth in foster care. Social Problems, 53(3), 371-391.

Pescosolido, B. (1992). Beyond rational choice: The social dynamics of how people seek help. American Journal of Sociology, 97(4), 1096-1138.

Robertson, J., Emerson, E., Gregory, N., Hatton, C., Kessissoglou, S., Hallam, A., \& Linehan, C. (2001). Social networks of people with mental retardation in residential settings. Mental Retardation, 39(3), 201-214.

Samuels, G.M. (2008). A reason, a season, or a lifetime: Relational permanence among young adults with foster care backgrounds. Chicago: Chapin Hall Center for Children at the University of Chicago.

Samuels, G. M. (2009). Ambiguous loss of home: The experience of familial (im)permanence among young adults with foster care backgrounds. Children and Youth Services Review, $31(12), 1229-1239$.

Samuels, G. M. \& Pryce, J. M. (2008). “What doesn't kill you makes you stronger”: Survivalist self-reliance as resilience and risk among young adults aging out of foster care. Children and Youth Services Review (30)10, 1198-1210. 
Sherbourne, C. D., \& Stewart, A. (1991). The MOS Social Support Survey. Social Science and Medicine, 32(6),705-714.

Stein, M. (2006). Young people aging out of care: The poverty of theory. Children and Youth Services Review, 28(4), 422-434.

Stiffman, A. R., Pescosolido, B., \& Cabassa, L. J. (2004). Building a model to understand youth service access: The Gateway Provider Model'. Mental Health Services Research, 6(4), 189-198.

Stott, T. (2013). Transitioning youth: Policies and outcomes. Children and Youth Services Review, 35(2), 218-227.

Tracy, E. M., \& Johnson, P. J. (2007). Personal social networks of women with co-occurring substance abuse and mental disorders. Journal of Social Work Practice in the Addictions, $7(1), 69-90$.

Tracy, E. M., \& Martin, T. C. (2007). Children's roles in the social networks of women in substance abuse treatment. Journal of Substance Abuse Treatment, 32(1), 81-88.

Tracy, E. M., \& Whittaker, J. K. (1990). The social network map: assessing social support in clinical practice. Families in Society: The Journal of Contemporary Human Services, 71(8), 461-470.

Tracy, E. M., \& Whittaker, J. K., Pugh, A., Kapp, S. N., \& Overstreet, E. J. (1994). Support networks of primary caregivers receiving family preservation services: an exploratory study. Families in Society, 75(8), 481-489.

Unrau, Y. A., Seita, J. R., \& Putney, K. S. (2008). Former foster youth remember multiple placement moves: A journey of loss and hope. Children and Youth Services Review, 30(11), 1256-1266. 
Walker, M., Wasserman, S., \& Wellman, B. (1993). Statistical models for social support networks. Sociological Methods \& Research, 22(1), 71.

Wellman, B. (1983). Network analysis: Some basic principles. Sociological Theory, 1, 155-200.

Wellman, B. (1988). Structural analysis: From method and metaphor to theory and substance. In B. Wellman \& S. D. Berkowitz (Eds.), Social Structures: A Network Approach. Cambridge: Cambridge University Press.

Wellman, B. (2007). Challenges in collecting personal network data: the nature of personal network analysis. Field Methods, 19(2), 111-115.

Wellman, B., \& Frank, K. (2001). Network capital in a multi-level world. In N. Lin, R. S. Burt, \& K. Cook (Eds.), Social Capital (pp. 233-273). Hawthorne, NY: Aldine de Gruyter.

Wellman, B., \& Gulia, M. (1999). The network basis of social support: A network is more than the sum of its ties. In B. Wellman (Ed.), Networks in the Global Village: Life in Contemporary Communities (pp. 83-118). Boulder, CO: Westview Press.

Wellman, B., \& Wortley, S. (1989). Brothers' keepers: Situating kinship relations in broader networks of social support. Sociological perspectives,32(3), 273-306.

Wellman, B., \& Wortley, S. (1990). Different strokes from different folks: Community ties and social support. American Journal of Sociology, 96(3), 558-588.

Wright, E. R. \& Pescosolido, B. A. (2002). "Sorry I forgot: the role of recall error in longitudinal personal network studies", In J. A. Levy \& B. A. Pescosolido (Eds.), Advances in medical sociology: Social networks and health, Vol. 8, pp. 113-129. Greenwich, CT: JAI Press.

Wulczyn, F., Kogan, J., \& Harden, B. J. (2003). Placement stability and movement trajectories. Social Service Review, 77(2), 212-236. 


\section{Tables and Figures}

Table 1. Sample demographics

\begin{tabular}{llcc}
\hline & & $\begin{array}{c}\text { Time 1 } \\
\text { (N=34) }\end{array}$ & $\begin{array}{c}\text { Time 2 } \\
\text { (N=27) }\end{array}$ \\
\hline Gender & Female & $22(65 \%)$ & $20(74 \%)$ \\
\hline Age & Mean $(S D)$ & $19.62(1.23)$ & $20.27(.245)$ \\
\hline \multirow{3}{*}{ Race/Ethnicity } & White & $18(53 \%)$ & $12(44 \%)$ \\
& Black/African American & $7(21 \%)$ & $7(26 \%)$ \\
& Hispanic/Latino & $4(12 \%)$ & $4(15 \%)$ \\
& Other or mixed race & $5(15 \%)$ & $4(15 \%)$ \\
\hline \multirow{4}{*}{ Living situation } & Lives with foster or adoptive family & $15(44 \%)$ & $8(30 \%)$ \\
& Lives with biological family & $4(12 \%)$ & $4(15 \%)$ \\
& Lives alone & $5(15 \%)$ & $7(26 \%)$ \\
& Lives with others (partners and/or roommates) & $10(29 \%)$ & $8(30 \%)$ \\
\hline \multirow{4}{*}{ Post-secondary } & $2(6 \%)$ & $6(22 \%)$ \\
enrollment & Not enrolled & $2(6 \%)$ & $2(7 \%)$ \\
& Community college transition program & $26(76 \%)$ & $13(48 \%)$ \\
& Enrolled in community college & $2(6 \%)$ & $2(7 \%)$ \\
& Enrolled in college/university & $2(6 \%)$ & $2(7 \%)$ \\
& Enrolled in other training program & $0(0 \%)$ & $2(7 \%)$ \\
\hline
\end{tabular}

a Includes participants who identified their race/ethnicity as follows at T1: White and Black/African American $(n=2)$, White and unknown race $(n=1)$, other Asian $(n=1)$, and American Indian/Alaskan Native $(n=1)$. 
Table 2. Network measurement

\begin{tabular}{|c|c|c|}
\hline Construct & Network Indicator & Operationalization \\
\hline \multirow{5}{*}{$\begin{array}{l}\text { Network } \\
\text { Capacity }\end{array}$} & Support network size & $\begin{array}{l}\text { The number of names generated by the network map as providing } \\
\text { any kind of support in the previous year. }\end{array}$ \\
\hline & Support network density & $\begin{array}{l}\text { The number of potential ties between identified names on the } \\
\text { network map that are actually present (excluding ties to the youth). }\end{array}$ \\
\hline & Support network range & $\begin{array}{l}\text { The number of map categories (FAMILY, FRIENDS, SCHOOL/WORK, } \\
\text { and/or OTHER) with at least one person identified as supporting } \\
\text { them in the past year. }\end{array}$ \\
\hline & Core network size & $\begin{array}{l}\text { The number of network map names }(0-10) \text { included on the core } \\
\text { relationship grid as providing support at least monthly. }\end{array}$ \\
\hline & Core role diversity & $\begin{array}{l}\text { The range of role designations (PARENT, SERVICE, or OTHER) } \\
\text { represented in the core, based on role descriptions designated as } \\
\text { parent figures and service-providing roles. }\end{array}$ \\
\hline \multirow{3}{*}{$\begin{array}{l}\text { Support } \\
\text { Provision }\end{array}$} & Total support provided & $\begin{array}{l}\text { Aggregate score }(0-120) \text { of each support type provided (0-3) within all } \\
\text { domains }(0-4) \text { for all core ties }(0-10) \text {. }\end{array}$ \\
\hline & Support by type & $\begin{array}{l}\text { Total for each support type provided (emotional, informational, } \\
\text { concrete) within four domains for up to ten ties (0-40). }\end{array}$ \\
\hline & Support per tie & Mean total support provided per core tie. \\
\hline
\end{tabular}


Table 3. Baseline descriptive variables

\begin{tabular}{|c|c|c|c|c|c|}
\hline Construct & Network Indicator & $M$ & SD & Min. & Max. \\
\hline \multirow{16}{*}{$\begin{array}{l}\text { Network } \\
\text { Capacity }\end{array}$} & Support network size & 10.65 & 4.01 & 3 & 19 \\
\hline & FAMILY & 2.94 & 2.20 & 0 & 9 \\
\hline & FRIENDS & 3.71 & 1.95 & 0 & 8 \\
\hline & SCHOOL/WORK & 2.21 & 2.03 & 0 & 8 \\
\hline & OTHER & 1.82 & 1.40 & 0 & 5 \\
\hline & Support network range $(1-3)^{a}$ & 2.82 & .46 & 1 & 3 \\
\hline & Support network density & .266 & .19 & .05 & .78 \\
\hline & Core network size $(0-10)$ & 6.79 & 2.66 & 3 & 10 \\
\hline & FAMILY in core & 2.41 & 1.89 & 0 & 8 \\
\hline & FRIENDS in core & 2.38 & 1.71 & 0 & 7 \\
\hline & SCHOOL/WORK in core & .82 & 1.11 & 0 & 4 \\
\hline & OTHER in core & 1.06 & 1.07 & 0 & 3 \\
\hline & Core role diversity (1-3 roles) & 2.32 & .73 & 1 & 3 \\
\hline & PARENT roles in core ${ }^{b}$ & 1.65 & 1.45 & 0 & 5 \\
\hline & SERVICE roles in core ${ }^{c}$ & 1.35 & 1.23 & 0 & 5 \\
\hline & All other roles in core & 3.79 & 2.19 & 0 & 8 \\
\hline \multirow{5}{*}{$\begin{array}{l}\text { Support } \\
\text { Provision }\end{array}$} & Total support (0-120) & 45.12 & 24.60 & 8 & 103 \\
\hline & Emotional support (0-40) & 18.29 & 10.07 & 1 & 35 \\
\hline & Informational support (0-40) & 14.68 & 8.99 & 1 & 35 \\
\hline & Concrete support (0-40) & 11.47 & 7.91 & 0 & 36 \\
\hline & Support per tie (0-12) & 6.65 & 2.70 & 2.00 & 12.00 \\
\hline
\end{tabular}

\footnotetext{
${ }^{a}$ The SCHOOL/WORK and OTHER categories are combined for a range of 1-3 categories.

${ }^{\mathrm{b}}$ Includes parents, step-parents, foster parents, grandparents, aunts/uncles.

${ }^{\mathrm{c}}$ Includes child welfare and ILP caseworkers, post-secondary program teachers/staff, or any paid workers.
} 
Table 4. Inter-item correlations

\begin{tabular}{|c|c|c|c|c|c|c|c|c|c|c|}
\hline \multicolumn{2}{|r|}{ Network Indicator } & $\begin{array}{l}\frac{0}{N} \\
\frac{N}{n} \\
\frac{1}{0} \\
\sum_{4}^{0} \\
\frac{0}{2}\end{array}$ & 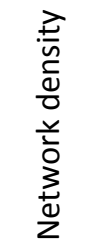 & 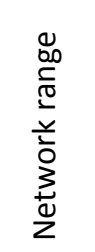 & 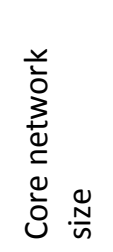 & 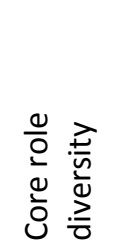 & 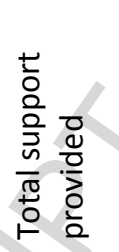 & 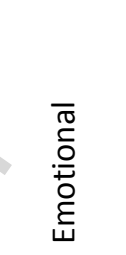 & 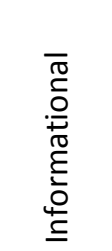 & 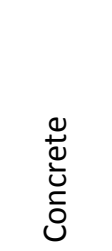 \\
\hline \multirow{4}{*}{ 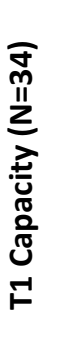 } & Network density ${ }^{a}$ & $-.403^{*}$ & -- & & & & & & & \\
\hline & Network range $^{a}$ & $.525 * *$ & -.191 & -- & & & & & & \\
\hline & Core network size ${ }^{a}$ & $.727 * *$ & -.271 & $.399 *$ & & & & & & \\
\hline & Core role diversity ${ }^{a}$ & $.447 * *$ & -.195 & $.347^{*}$ & $.605 * *$ & -- & & & & \\
\hline \multirow{5}{*}{ 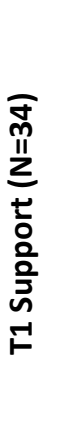 } & Total support ${ }^{\mathrm{a}}$ & $.528 * *$ & -.067 & .225 & $.539 * *$ & $.362^{*}$ & -- & & & \\
\hline & Emotional & $.559 * *$ & -.062 & .128 & $.637 * *$ & $.450 *$ & $.840 * *$ & -- & & \\
\hline & Informational & $.532 * *$ & & .063 & $.603 * *$ & $.434^{*}$ & $.842 * *$ & $.782 * *$ & -- & \\
\hline & Concrete & $.372 *$ & & 184 & $.391 *$ & .251 & $.737 * *$ & $.513 * *$ & $.702 * *$ & -- \\
\hline & Support per tie & .032 & & -.232 & -.082 & -.005 & $.715^{* *}$ & $.462 * *$ & $.588 * *$ & $.607 * *$ \\
\hline \multirow{4}{*}{ 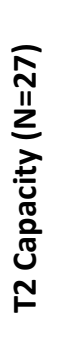 } & Network density ${ }^{a}$ & & & & & & & & & \\
\hline & Network range $^{a}$ & .351 & -.257 & -- & & & & & & \\
\hline & Core network size ${ }^{a}$ & $.756 * *$ & .051 & .054 & -- & & & & & \\
\hline & Core role diversity $^{\mathrm{a}}$ & .257 & -.068 & .150 & $.385 *$ & -- & & & & \\
\hline \multirow{5}{*}{ 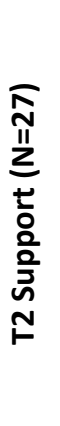 } & Total support & $.478 *$ & -.091 & .061 & $.697^{* *}$ & -.043 & -- & & & \\
\hline & Emotional & $.696 * *$ & -.154 & .091 & $.743 * *$ & .091 & $.878 * *$ & -- & & \\
\hline & Informational & .372 & -.206 & .030 & $.661^{* *}$ & -.036 & $.958 * *$ & $.781 * *$ & -- & \\
\hline & Concrete & .244 & .079 & .015 & $.516 * *$ & -.217 & $.901 * *$ & $.629 * *$ & $.838 * *$ & -- \\
\hline & Support per tie & .047 & -.260 & .061 & .126 & $-.392^{*}$ & $.754 * *$ & $.508 * *$ & $.754^{* *}$ & $.799 * *$ \\
\hline
\end{tabular}

${ }^{a}$ Not normally distributed. Correlation is Spearman's rho.

$* p<.05$.

$* * p<.01$. 
Table 5. Test-retest reliability $(n=27)$

\begin{tabular}{|c|c|c|c|c|}
\hline Construct & Network Indicator & $\mathrm{T} 1 M(S D)$ & $\mathrm{T} 2 M(S D)$ & Correlation \\
\hline \multirow{14}{*}{$\begin{array}{l}\text { Network } \\
\text { Capacity }\end{array}$} & Support network size & $10.59(4.12)$ & $13.52(5.10)$ & $.56 * *$ \\
\hline & Support network range (0-3) & $2.89(.32)^{\mathrm{a}}$ & $2.89(.32)^{a}$ & $.63 * *$ \\
\hline & FAMILY & $2.81(2.08)^{a}$ & 4.11 (1.99) & $.57 * *$ \\
\hline & FRIENDS & $3.67(1.88)$ & $4.63(3.05)$ & $.60 *$ \\
\hline & SCHOOL/WORK/OTHER & $4.15(2.60)^{\mathrm{a}}$ & $4.78(2.29)$ & .14 \\
\hline & Support network density & $.28(.20)^{\mathrm{a}}$ & $.24(.133)^{a}$ & .37 \\
\hline & Core network size (0-10) & $6.74(2.70)^{a}$ & $7.52(2.55)^{a}$ & $.77 * *$ \\
\hline & FAMILY & $2.48(1.95)^{a}$ & $2.93(1.64)^{\mathrm{a}}$ & $.56 * *$ \\
\hline & FRIENDS & $2.26(1.51)^{a}$ & $2.41(1.91)^{\mathrm{a}}$ & .36 \\
\hline & SCHOOL/WORK/OTHER & $1.96(1.48)$ & $2.15(1.81)^{\mathrm{a}}$ & $.47 *$ \\
\hline & Core role diversity (0-3) & $2.26(.712)^{a}$ & $2.33(.679)^{\mathrm{a}}$ & $.37 t$ \\
\hline & PARENT roles in core & $1.63(1.57)^{\mathrm{a}}$ & $1.67(1.39)^{\mathrm{a}}$ & $.70 * *$ \\
\hline & SERVICE roles in core & $1.41(1.39)^{\mathrm{a}}$ & $1.19(1.36)^{\mathrm{a}}$ & $.51 * *$ \\
\hline & All other roles in core & $3.70(2.05)$ & $4.67(2.35)$ & $.62 * *$ \\
\hline \multirow{5}{*}{$\begin{array}{l}\text { Support } \\
\text { Provision }\end{array}$} & Total support (0-120) & $46.70(26.72)^{a}$ & $57.59(27.74)$ & $.47 *$ \\
\hline & Emotional support (0-40) & $18.44(10.48)$ & $23.67(9.91)$ & $.68^{* *}$ \\
\hline & Informational support (0-40) & 14.85 (9.39) & $18.11(10.38)$ & $.64 * *$ \\
\hline & Concrete support (0-40) & $12.56(8.48)$ & $15.74(10.01)$ & $.56 * *$ \\
\hline & Support per tie (0-12) & $6.73(2.63)$ & $7.50(2.51)$ & $.44^{*}$ \\
\hline
\end{tabular}

${ }^{a}$ Not normally distributed. Reported correlation value is Spearman's rho.

$* \mathrm{p}<.05$.

$* * \mathrm{p}<.01$.

$+p<.10$. 
Table 6. Construct validity of network-based support provision with perceived social support

\begin{tabular}{|c|c|c|c|c|c|}
\hline \multirow[b]{2}{*}{ Network-based support } & \multicolumn{5}{|c|}{ MOS subscale scores } \\
\hline & Sum score ${ }^{a}$ & $\begin{array}{c}\text { Emotional/ } \\
\text { Informational }^{\mathrm{a}}\end{array}$ & Tangible $^{a}$ & $\begin{array}{c}\text { Positive } \\
\text { interaction }^{\mathrm{a}}\end{array}$ & Affectionate $^{a}$ \\
\hline Total support provided & $.561 * *$ & $.600 * *$ & $.449 *$ & $.478 *$ & .365 \\
\hline Emotional support & $.389 *$ & $.410 *$ & .292 & .311 & .133 \\
\hline Informational support & $.545 * *$ & $.642 * *$ & $.428 *$ & .379 & .303 \\
\hline Concrete support & $.539 * *$ & $.563 * *$ & $.450 *$ & $.514^{* *}$ & $.454^{*}$ \\
\hline
\end{tabular}

${ }^{a}$ Not normally distributed. Reported correlation value is Spearman's rho.

$* \mathrm{p}<.05$.

$* * p<.01$. 
Table 7. Predictive validity by network-based support provision and perceived social support

\begin{tabular}{|c|c|c|c|}
\hline & & & \\
\hline & Not enrolled & Enrolled/graduated & $\boldsymbol{P}$ \\
\hline \multicolumn{4}{|l|}{ Network-based support provision } \\
\hline T1 Total support provided $(0-120)^{a}$ & 23.33 & 53.38 & .031 \\
\hline T1 Emotional support provided (0-40) & 9.33 & 21.05 & .013 \\
\hline $\mathrm{T} 1$ Informational support provided $(0-40)^{\mathrm{b}}$ & 6.50 & 17.24 & .010 \\
\hline T1 Concrete support provided $(0-40)^{a}$ & 7.50 & 14.00 & .070 \\
\hline T2 Total support provided $(0-120)$ & 32.83 & 64.67 & .010 \\
\hline T2 Emotional support provided (0-40) & 14.33 & 26.33 & .006 \\
\hline T2 Info. support provided (0-40) & 9.33 & 20.62 & .016 \\
\hline T2 Concrete support provided $(0-40)$ & 9.17 & 17.62 & .067 \\
\hline \multicolumn{4}{|l|}{ MOS support variables } \\
\hline T1 sum score $(19-95)^{a}$ & 69.33 & 78.38 & .413 \\
\hline T1 emotional/informational scale $(1-5)^{\mathrm{a}}$ & 3.42 & 3.97 & .428 \\
\hline $\mathrm{T} 1$ tangible support scale $(1-5)^{\mathrm{a}}$ & 3.88 & 4.04 & .459 \\
\hline $\mathrm{T} 1$ positive interaction scale $(1-5)^{\mathrm{a}}$ & 3.67 & 4.41 & .070 \\
\hline T1 affectionate support scale $(1-5)^{\mathrm{a}}$ & 3.83 & 4.35 & .131 \\
\hline T2 sum score $(19-95)^{\mathrm{a}}$ & 75.83 & 83.00 & .159 \\
\hline T2 emotional/informational scale $(1-5)^{\mathrm{a}}$ & 3.69 & 4.23 & .317 \\
\hline T2 tangible support scale $(1-5)^{\mathrm{a}}$ & 3.88 & 4.35 & .228 \\
\hline T2 positive interaction scale $(1-5)^{a}$ & 4.22 & 4.62 & .058 \\
\hline T2 affectionate support scale $(1-5)^{\mathrm{a}}$ & 4.50 & 4.49 & .584 \\
\hline
\end{tabular}

${ }^{a}$ Variable is not normally distributed. P-value is for the non-parametric Mann-Whitney $U$ test.

'Variable fails Levene's test of homogeneity of variance. P-value is for the Welch statistic. 


\section{Appendix A. Network Assessment Instrument}

\section{Support Network Map}

FIRST, please write down the people (first name or initials) who have supported you in the last year and draw a line between your name and theirs. NEXT, draw a line between any two people in your network that also know each other.

LASTLY, highlight the relationships that provide support to you at least once a month-who in your network regularly provides support to you?

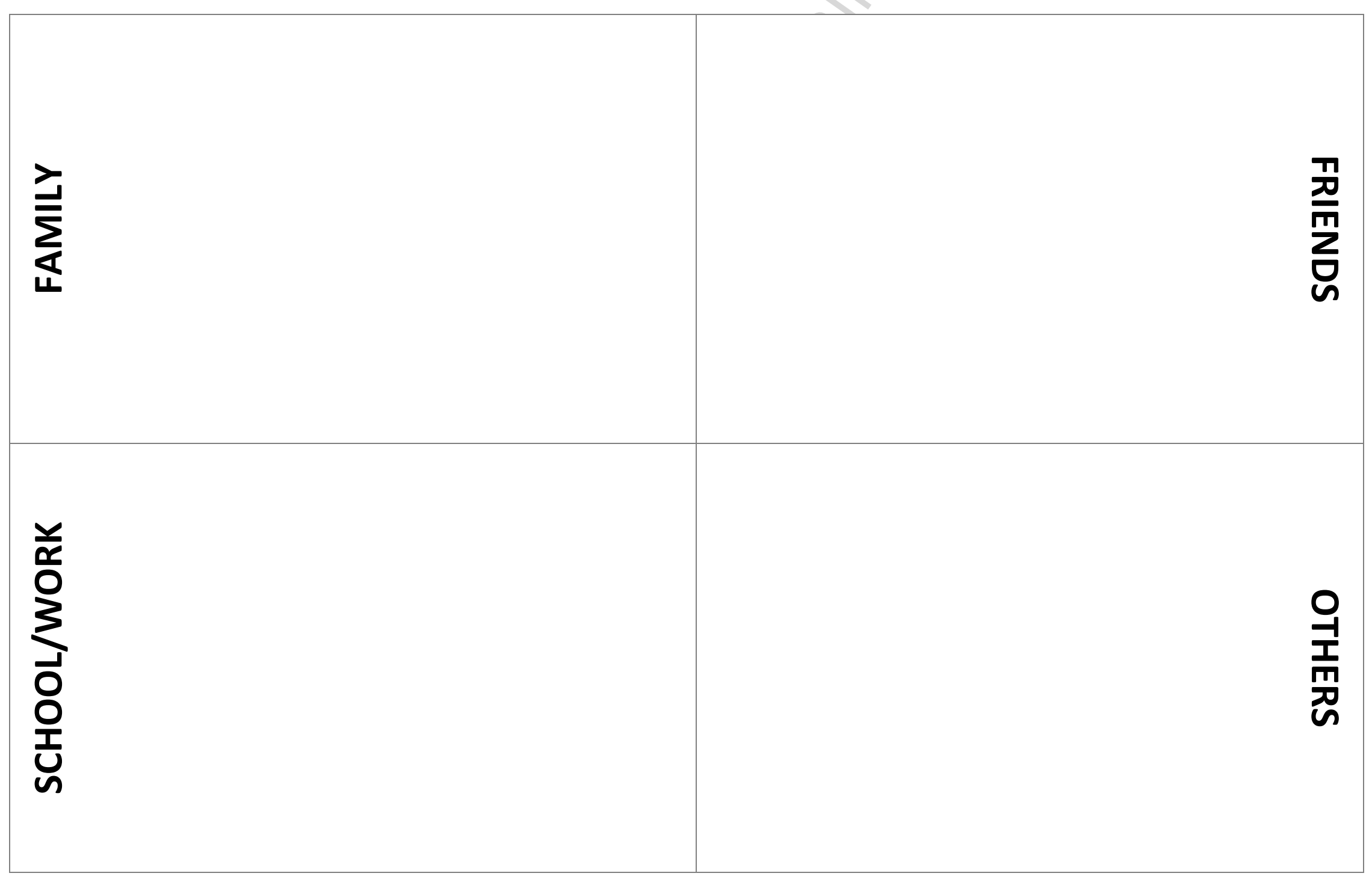




\section{Support Network Grid}

FIRST, write down the people from your network map who support you at least monthly, and say what role they have in your life (caseworker, aunt, etc.).

NEXT, within each of the four domains, circle any of the type(s) of support that person provides-for example, they may give you academic support by offering advice, or give you social support by listening when you talk about things that are important to you, or help with career prep by offering you a ride to an interview. (Note that some people may only support you in one or two ways in one or two domains.)

LASTLY, circle how often they support you (for example, you see them every day, or they call you once a week, or meet with you each month), how close you feel to them, and how long you've known them.

\begin{tabular}{|c|c|c|c|c|c|c|c|c|}
\hline $\begin{array}{c}\text { First Name } \\
\text { or Initials }\end{array}$ & $\begin{array}{l}\text { Person's Role } \\
\text { in Your Life }\end{array}$ & $\begin{array}{l}\text { Academic } \\
\text { Support }\end{array}$ & $\begin{array}{l}\text { Career } \\
\text { Prep }\end{array}$ & $\begin{array}{l}\text { Extra- } \\
\text { curricular }\end{array}$ & $\begin{array}{l}\text { Social } \\
\text { Support }\end{array}$ & $\begin{array}{l}\text { How } \\
\text { often? }\end{array}$ & $\begin{array}{l}\text { How } \\
\text { close? }\end{array}$ & How long? \\
\hline & & $\begin{array}{l}\text { Talk to them } \\
\text { Get info/guidance } \\
\text { Ask for favors }\end{array}$ & $\begin{array}{l}\text { Talk to them } \\
\text { Get info/guidance } \\
\text { Ask for favors }\end{array}$ & $\begin{array}{l}\text { Talk to them } \\
\text { Get info/guidance } \\
\text { Ask for favors }\end{array}$ & $\begin{array}{l}\text { Talk to them } \\
\text { Get info/guidance } \\
\text { Ask for favors }\end{array}$ & $\begin{array}{l}\text { Daily } \\
\text { Weekly } \\
\text { Monthly }\end{array}$ & $\begin{array}{l}\text { Not close } \\
\text { Close } \\
\text { Very close }\end{array}$ & $\begin{array}{l}\text { Less than a year } \\
1-5 \text { years } \\
\text { More than five }\end{array}$ \\
\hline & & $\begin{array}{l}\text { Talk to them } \\
\text { Get info/guidance } \\
\text { Ask for favors }\end{array}$ & $\begin{array}{l}\text { Talk to them } \\
\text { Get info/guidance } \\
\text { Ask for favors }\end{array}$ & $\begin{array}{l}\text { Talk to them } \\
\text { Get info/guidance } \\
\text { Ask for favors }\end{array}$ & $\begin{array}{l}\text { Talk to them } \\
\text { Get info/guidance } \\
\text { Ask for favors }\end{array}$ & $\begin{array}{l}\text { Daily } \\
\text { Weekly } \\
\text { Monthly }\end{array}$ & $\begin{array}{l}\text { Not close } \\
\text { Close } \\
\text { Very close }\end{array}$ & $\begin{array}{l}\text { Less than a year } \\
1-5 \text { years } \\
\text { More than five }\end{array}$ \\
\hline & & $\begin{array}{l}\text { Talk to them } \\
\text { Get info/guidance } \\
\text { Ask for favors }\end{array}$ & $\begin{array}{l}\text { Talk to them } \\
\text { Get info/guidance } \\
\text { Ask for favors }\end{array}$ & $\begin{array}{l}\text { Talk to them } \\
\text { Get info/guidance } \\
\text { Ask for favors }\end{array}$ & $\begin{array}{l}\text { Talk to them } \\
\text { Get info/guidance } \\
\text { Ask for favors }\end{array}$ & $\begin{array}{l}\text { Daily } \\
\text { Weekly } \\
\text { Monthly }\end{array}$ & $\begin{array}{l}\text { Not close } \\
\text { Close } \\
\text { Very close }\end{array}$ & $\begin{array}{l}\text { Less than a year } \\
1-5 \text { years } \\
\text { More than five }\end{array}$ \\
\hline & & $\begin{array}{l}\text { Talk to them } \\
\text { Get info/guidance } \\
\text { Ask for favors }\end{array}$ & $\begin{array}{l}\text { Talk to them } \\
\text { Get info/guidance } \\
\text { Ask for favors }\end{array}$ & $\begin{array}{l}\text { Talk to them } \\
\text { Get info/guidance } \\
\text { Ask for favors }\end{array}$ & $\begin{array}{l}\text { Talk to them } \\
\text { Get info/guidance } \\
\text { Ask for favors }\end{array}$ & $\begin{array}{l}\text { Daily } \\
\text { Weekly } \\
\text { Monthly }\end{array}$ & $\begin{array}{l}\text { Not close } \\
\text { Close } \\
\text { Very close }\end{array}$ & $\begin{array}{l}\text { Less than a year } \\
1-5 \text { years } \\
\text { More than five }\end{array}$ \\
\hline & & $\begin{array}{l}\text { Talk to them } \\
\text { Get info/guidance } \\
\text { Ask for favors }\end{array}$ & $\begin{array}{l}\text { Talk to them } \\
\text { Get info/guidance } \\
\text { Ask for favors }\end{array}$ & $\begin{array}{l}\text { Talk to them } \\
\text { Get info/guidance } \\
\text { Ask for favors }\end{array}$ & $\begin{array}{l}\text { Talk to them } \\
\text { Get info/guidance } \\
\text { Ask for favors }\end{array}$ & $\begin{array}{l}\text { Daily } \\
\text { Weekly } \\
\text { Monthly }\end{array}$ & $\begin{array}{l}\text { Not close } \\
\text { Close } \\
\text { Very close }\end{array}$ & $\begin{array}{l}\text { Less than a year } \\
1-5 \text { years } \\
\text { More than five }\end{array}$ \\
\hline & & $\begin{array}{l}\text { Talk to them } \\
\text { Get info/guidance } \\
\text { Ask for favors }\end{array}$ & $\begin{array}{l}\text { Talk to them } \\
\text { Get info/guidance } \\
\text { Ask for favors }\end{array}$ & $\begin{array}{l}\text { Talk to them } \\
\text { Get info/guidance } \\
\text { Ask for favors }\end{array}$ & $\begin{array}{l}\text { Talk to them } \\
\text { Get info/guidance } \\
\text { Ask for favors }\end{array}$ & $\begin{array}{l}\text { Daily } \\
\text { Weekly } \\
\text { Monthly }\end{array}$ & $\begin{array}{l}\text { Not close } \\
\text { Close } \\
\text { Very close }\end{array}$ & $\begin{array}{l}\text { Less than a year } \\
1-5 \text { years } \\
\text { More than five }\end{array}$ \\
\hline & & $\begin{array}{l}\text { Talk to them } \\
\text { Get info/guidance } \\
\text { Ask for favors }\end{array}$ & $\begin{array}{l}\text { Talk to them } \\
\text { Get info/guidance } \\
\text { Ask for favors }\end{array}$ & $\begin{array}{l}\text { Talk to them } \\
\text { Get info/guidance } \\
\text { Ask for favors }\end{array}$ & $\begin{array}{l}\text { Talk to them } \\
\text { Get info/guidance } \\
\text { Ask for favors }\end{array}$ & $\begin{array}{l}\text { Daily } \\
\text { Weekly } \\
\text { Monthly }\end{array}$ & $\begin{array}{l}\text { Not close } \\
\text { Close } \\
\text { Very close }\end{array}$ & $\begin{array}{l}\text { Less than a year } \\
1-5 \text { years } \\
\text { More than five }\end{array}$ \\
\hline & & $\begin{array}{l}\text { Talk to them } \\
\text { Get info/guidance } \\
\text { Ask for favors }\end{array}$ & $\begin{array}{l}\text { Talk to them } \\
\text { Get info/guidance } \\
\text { Ask for favors }\end{array}$ & $\begin{array}{l}\text { Talk to them } \\
\text { Get info/guidance } \\
\text { Ask for favors }\end{array}$ & $\begin{array}{l}\text { Talk to them } \\
\text { Get info/guidance } \\
\text { Ask for favors }\end{array}$ & $\begin{array}{l}\text { Daily } \\
\text { Weekly } \\
\text { Monthly }\end{array}$ & $\begin{array}{l}\text { Not close } \\
\text { Close } \\
\text { Very close }\end{array}$ & $\begin{array}{l}\text { Less than a year } \\
1-5 \text { years } \\
\text { More than five }\end{array}$ \\
\hline & & $\begin{array}{l}\text { Talk to them } \\
\text { Get info/guidance } \\
\text { Ask for favors }\end{array}$ & $\begin{array}{l}\text { Talk to them } \\
\text { Get info/guidance } \\
\text { Ask for favors }\end{array}$ & $\begin{array}{l}\text { Talk to them } \\
\text { Get info/guidance } \\
\text { Ask for favors }\end{array}$ & $\begin{array}{l}\text { Talk to them } \\
\text { Get info/guidance } \\
\text { Ask for favors }\end{array}$ & $\begin{array}{l}\text { Daily } \\
\text { Weekly } \\
\text { Monthly }\end{array}$ & $\begin{array}{l}\text { Not close } \\
\text { Close } \\
\text { Very close }\end{array}$ & $\begin{array}{l}\text { Less than a year } \\
1-5 \text { years } \\
\text { More than five }\end{array}$ \\
\hline & & $\begin{array}{l}\text { Talk to them } \\
\text { Get info/guidance } \\
\text { Ask for favors }\end{array}$ & $\begin{array}{l}\text { Talk to them } \\
\text { Get info/guidance } \\
\text { Ask for favors }\end{array}$ & $\begin{array}{l}\text { Talk to them } \\
\text { Get info/guidance } \\
\text { Ask for favors }\end{array}$ & $\begin{array}{l}\text { Talk to them } \\
\text { Get info/guidance } \\
\text { Ask for favors }\end{array}$ & $\begin{array}{l}\text { Daily } \\
\text { Weekly } \\
\text { Monthly }\end{array}$ & $\begin{array}{l}\text { Not close } \\
\text { Close } \\
\text { Very close }\end{array}$ & $\begin{array}{l}\text { Less than a year } \\
1-5 \text { years } \\
\text { More than five }\end{array}$ \\
\hline
\end{tabular}




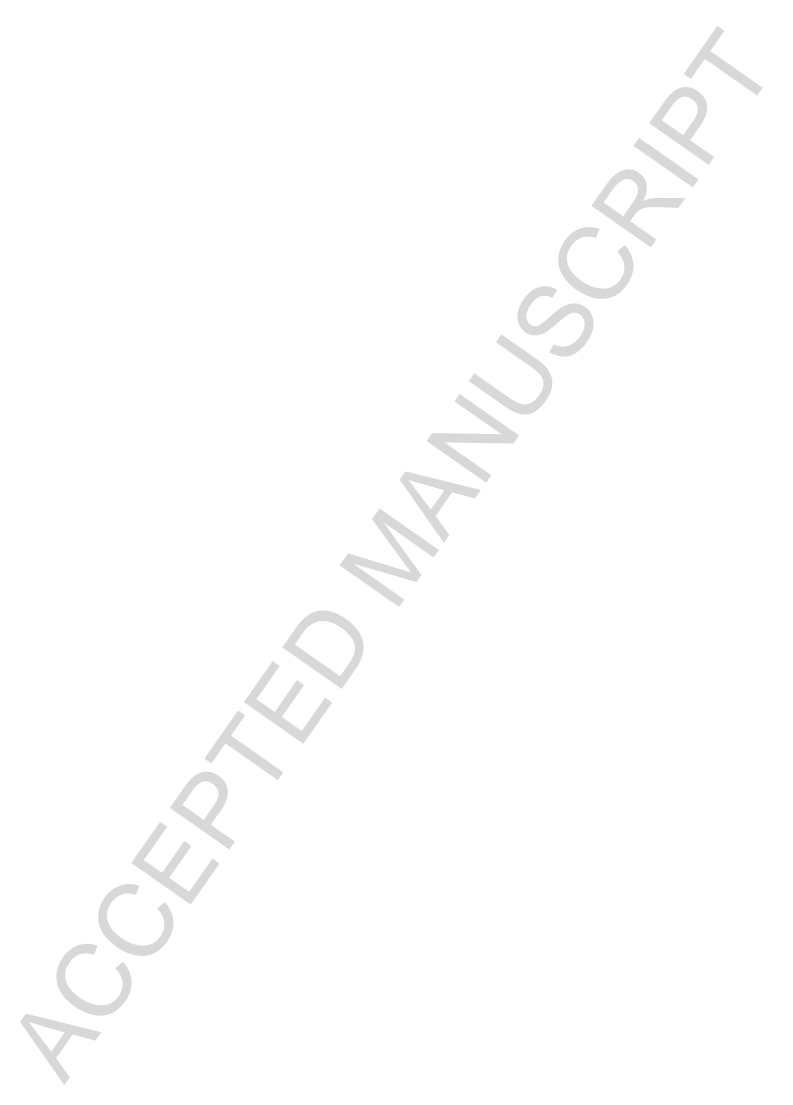




\section{Highlights}

- This paper presents a support network measurement approach for older foster youth

- Support networks are described for a sample of service-connected youth

- Reliability findings show consistent measurement over time on many indicators

- Validity findings show that this approach measures related social support constructs

- This measure of support better predicted post-secondary enrollment at follow-up 